\title{
The Impact of Management the Structure of Agribusiness on Development of Economy: Evidence from Republic of Kosovo
} Sylejmani B*

Department of Management and Informatics, University of Prishtina, Republic of Kosovo

\begin{abstract}
In this paper, we investigate the impact of management the structure of agribusiness on economy as a direct influence on Kosovo's development and on the harmonization of people needs on rural areas. Also, the perceptions of farmers about the agribusiness. Using the principal component and regression analyses based on data obtained from 190 interviews with farmers' ten different municipalities. The study reveals that farmers have high favorable perception of agribusiness, and the economic development is influenced by the type of modes management structure used, the harmonization of people needs on rural areas is not. Thus, the economic dimension improves as the farmers adopt a more coordinated type of mode management of structure. We conclude that farmers should adopt a more coordinated type of modes structure of management of their farms; this will contribute to the employment and overall development of economy.
\end{abstract}

Keywords: Management of structure; Economy; Harmonization of needs; Agriculture; Farms; Kosovo

\section{Introduction}

\section{Background}

Researches in the farm management field widely agree that the way the farmer manage the structure of their activity is one of the most important element on their productivity [1-5]. Rougoor et al. [6] defined management capacity "as personal characteristics and skills to deal with the right problems and opportunities, in the right moment and in the right way" (p. 262). Also Davis and Ray defined the management of agribusiness as a sum total of all operations involved in the Agribusiness [7].

McConnell and Dillon noted that are four modes of structure farm management within fields which are: Analyzers and Descriptive, Identifying and React, Diagnostic and Oversight, Operational and Controlling [8]. Gandhi noticed that agribusiness is rapidly turning into important factor, Goldsmith said that farmers should pay attention the way they manage their farmers $[9,10]$. So Dobermann and Nelson empathize that management as a significant impact on economy of the country [11]. Acharya highlighted the impact development of economy from agriculture [12], whilst Schickele said that when economy increase this will help farmers to have more opportunity to developed the range of their products [13]. Stanton arguments that a good structure of management of agriculture will effect on increasing income of the country [14].

The previous studies on have mainly been concerned the policy, and financial resources [15-20]. Further, the effect of structure management of agribusiness has been treated in many studies my using the different models and analysis methods, but the impact of structure type of modes management of agribusiness as an independent variable has gained much less attention.

The purpose of this paper is to advance understanding the management structure of farms, by analyzing the impact of types management of structure in the economy of Kosovo and harmonization the people's needs on rural areas and to discover the perception of farmers about agribusiness. The remaining parts of the paper are organized as follows: First, we provide an overview about the previous studies on the concepts development of economy from agribusiness and the impact of structure management of farms as an important element to develop agribusiness.

Following, we present the perceptions of farmers for agribusiness, and compare the impact of types modes of management structure of farmers and determine their effects. Finally, managerial implications for the study and the direction for future research are provided.

\section{Literature Review}

\section{Role of agribusiness in the economy}

Kosovo is one of the last countries in the region to start the transition process to establish a market economy Kutllovci and Shala [21]. According to Statistic office of Kosovo [22] agriculture is one of the most important sectors of the economy, so the Enhance youth Europe [23] highlighted as a rich tradition furthermore Zejnullahi said that is an integral part of the country's history, consciousness and cultural heritage [24]. Task Force on European Integration Kosovo Agency of Statistics [25] shows the employment rate in agriculture of $4.4 \%$ while the number of rural population is $1,078,239$ or $61.97 \%$, while Gjokaj et al. [20] empathize that this sector contributes 12\% to the GDP (gross domestic product) of Kosovo and accounts for over $25 \%$ of total employment.

Task Force on European Integration [26] considers the agriculture sector an important role in providing employment opportunities and generating incomes for the inhabitants living in these areas. USIAD [27] said that the government of Kosovo should invest more on rural areas. The European Commission [28] highlighted the importance of substantial investments on agribusiness. Furthermore, Miftari et al. adds that on view of the weakness and inadequate growth rates of other sectors of Kosovo's economy, agricultural sector is of particular

${ }^{*}$ Corresponding author: Blinera Sylejmani, Department of Management and Informatics, University of Prishtina, Republic of Kosovo, Tel: 38138244183/244186, Fax: 38138244187; E-mail: blinerasylejmani1992@gmail.com

Received October 20, 2018; Accepted November 22, 2018; Published November 26, 2018

Citation: Sylejmani B (2018) The Impact of Management the Structure of Agribusiness on Development of Economy: Evidence from Republic of Kosovo. Int J Econ Manag Sci 7: 549. doi: 10.4172/2162-6359.1000549

Copyright: (c) 2018 Sylejmani B. This is an open-access article distributed under the terms of the Creative Commons Attribution License, which permits unrestricted use, distribution, and reproduction in any medium, provided the original author and source are credited. 
importance with a view to accelerating the growth of Kosovo's economy, improving the trade balance [29].

European Fund for Southeast Europe [30] points out that the Ministry of Agriculture, Forestry and Rural Development (MAFRD) as a implementing institution and the managing authority of the government's agricultural which is revised every four years includes detailed sub-sector strategies, for the key commodities aiming to restructure the agricultural sector and fulfill the requirements of Kosovo, also the World Bank [31] said that Kosovo has adopted long- or midterm strategic documents such as: the National Agriculture Development Strategy (ARDP 2014-2020), the Mid-Term Expenditure Framework (MTEF), Yearly National Program for Agriculture and Rural Development and the Economic Reform Program, in which objectives and priorities for agriculture and rural development were set.

Moreover, The European Commission said that farmers in Kosovo are faced with several constrains such as fragmented agricultural land, outdated farm technologies, lack of diversification of agricultural products, high costs, limited capacity and limited provision of technical support [32]. Furthermore, the Ministry of Agriculture, Forestry and Rural Development - MAFRD said that more attention should also be given to the less favored areas (hillsides, land rolling, etc.) and to the farmers of these zones where the productivity is lower [33]. In addition, European Commission and the World Bank empathize that the development of legislation for decoupled payments is needed, but this development depends on the organizational and human capacity strengthening and the financial sustainability [34].

\section{Management structure of farms as an important element for developing Agribusiness}

Rougoor define management capacity important, while Arabiun empathises that the management as one of the important elements for developing agribusiness [35]. Makinen said that different management accounting tools aid the manager in decision- making and in assessment of farm performance [36].

The National Center for Appropriate Technology -NCAT, said that choosing the structure for your farm is an important decision for beginning farmers [37]. The farm business structure will affect the legal and tax liability of your farm. While the International Institute for Environment and Development- IIED empathize that management structure on farms is very important, is a significant factor that make people in farm to work better and to realize farm's objective, further said that is farms should pay close attention to their structure of their farms this will effect on develop agribusiness in a significant way [38]. Wolz et al. points out that employees are important for Agribusiness, the best way to make employees productive while their working, is to knowing how to manage and make them feel comfortable in theirs work [39].

Gunderson et al. farms must predict several future indicators on to have that can effect on their activity [40]. Furthermore, Mustafa points out as a challenge of all spending units for an efficient budget management remains the profound linkage of planning and spending [41], and according to Balzas et al. farm records are a vital management tool, and sustainable land management systems use structures and sectors which are appropriate to the environmental conditions, adapting to the environment, expressing the environment's potential to the greatest possible extent [42-44]. Business planning and management is a relatively straightforward procedure, providing that certain basic steps are followed. Reliable information, however, is the key to any agribusiness planning activity.

\section{Hypotheses}

Sustained economic growth in Kosovo cannot depend only agribusiness sector, however this sector is considered to have the greatest potential for improving the country's economic situation. And the impact of management of structure of farms is inevitable. McConnell and Dillon emphasized that each mode of structure management of farms as a form of using resources helps farmers to achieving specified objective, and this directly affect in the income of country. We therefore hypothesize that:

Hypothesis 1: Different modes of structure management are associated with different impacts in development of economy

The share of the rural population in the total population is about $60 \%$. More than half of the workforce is unemployed. Unemployment in rural areas is $54.5 \%$ ( $44 \%$ in urban areas). Main sources of income of rural households: wages (58.0\%), remittances (14.1\%), agriculture income $(9.1 \%)$, pensions, social assistance $(7.4 \%)$, others $(11.4 \%)$ (Riinvest2004). To increase the incomes in those areas farmers should pay more attention to the structure of management of their farms as direct factor to improve people life in rural areas.

We therefore hypothesize that:

Hypothesis 2: Change of the use modes of structure management can have effect on the harmonization of needs of people on rural areas.

\section{Methodology}

Kosovo is a country with a total area of $10,908 \mathrm{~km}^{2}$ and an estimated population of 1.8 million. According to the latest statistics, the total agricultural land of Kosovo amounts at 277,364 ha of which 253,563 ha is arable land, 7,071 ha land under permanent crops (orchards and vineyards), and 97,114 ha land under permanent grassland (meadows and pastures). The total farm land is used by 185,765 farms out of which $185,424(99 \%)$ are small farms.

The research was generally focused on municipalities with more intensive agriculture and significantly greater number of registered agricultural farms. The research study was carried out in ten different municipalities such as Prishtina, Podujeva, Rahovec, Mamusha, Gjilan, Gjakova, Dragash, Istog, Skenderaj and Drenas based on the lists provided by the Departments of Agriculture. The survey covers various branch of agriculture sector (orcharding, vegetables, livestock, arable crops, vineyards, beekeeping and others). Table 1 summarizes the sampling procedure and the sample size.

\begin{tabular}{|c|c|c|}
\hline Demographic Variables & Items & Count \\
\hline Gender & Male & 94.7 \\
\hline & Female & 5.3 \\
\hline Age & below 25 years & 2.6 \\
\hline & $26-30$ years & 2.6 \\
\hline & $31-35$ years & 0.5 \\
\hline & $36-40$ years & 2.6 \\
\hline Level of education & $41-45$ years & 21.1 \\
\hline & $46-50$ years & 35.8 \\
\hline & More than 50 years & 34.7 \\
\hline Farming experience & Homaduate or Less & 8.9 \\
\hline & Collage/Assoc. Degree & 67.9 \\
\hline & $1-10$ years & 23.2 \\
\hline & $11-15$ years & 20.5 \\
\hline & $15-20$ years & 22.6 \\
\hline & More than 20 years & 26.8 \\
\hline
\end{tabular}

Table 1: Respondents' profile $(n=190)$ 
Citation: Sylejmani B (2018) The Impact of Management the Structure of Agribusiness on Development of Economy: Evidence from Republic of Kosovo. Int J Econ Manag Sci 7: 549. doi: 10.4172/2162-6359.1000549

Page 3 of 5

We used SPSS statistical program version 20 for all statistical computations. Structured questionnaire was used for data collection in the location of the farms. The questionnaire was pre-tested with twelve farmers. The participants were asked to comment on the format of the questionnaire including the aspects like wording, length, and the order of the questions. After, the feedback obtained was incorporate to improve the questionnaire (Table 2).

In order to test the first hypothesis, the dependent variable which is the changes in the economy and the independent variables are modes of structure management. We operationalized modes of structure of management as a higher order construct made up of a combination of several factors. The items used to operationalize the modes of structure of management were adapted from some articles on field of management and agribusiness including McConnell and Dillon, Gunderson, Boehlje, Neves, Sonka and Beilock. All the mode of structure of management were measured on a five-point Likert scale system ( $1=$ strongly disagree and $5=$ strongly agree). The independent variable is the improvement of changes in the economy, were adapted from Mustafa and Ekrem. The impact on development economy was measured on a simple scale system $1=$ Yes, $2=$ No.

Reference category: Impact of agribusiness

Independent variables: Types of structure management

Dependent variable: Changes in the economy

To test the second hypothesis, this establishes the effects of the use modes of structure management on harmonization of needs on rural areas. We used the same items as the first hypothesis. As dependent variable is harmonization of needs on rural areas, were adopted from Nicholson 2004.

Reference category: Impact of agribusiness
Independent variables: Types of structure management

Dependent variable: Harmonization of needs on rural areas

The harmonization of needs on rural was measured on a simple scale system $1=$ Yes, $2=$ No. We used linear regression to measure how a dependent variable anticipates the independent variable, the results of the regression models are indicated in Tables 3 and 4 .

\section{Results and Discussion}

\section{Respondents' profile}

The study revealed that $97.7 \%$ of the respondents were male, while only $5.3 \%$ were female. We have observed that males could readily be available for managing agribusiness. The low percentage of the female participating in agribusiness activities could be attributed to the fact that females in the study area usually involved in several other activities outside farming like food vendors, hair dressing, tailoring and petty trading. The findings reveal the majority of farmers are aged between $46-50$ years $(35.8 \%)$, we can say that they are in their productive age, where their experience could be harnessed and utilized for productive venture in agriculture. Most of farms (67.9\%) had at least Collage/ Assoc. degree, we can have noted that this level of education influences a farmer's decision, awareness, perception of the impact of structure management on farms. $30.0 \%$ of farmers have farming experience more than 20 years, that is a very important factor to stay in competitive market and to know what mode of structure of management to use to increase their incomes and to help the economy of country.

\section{Farmers' perception of agribusiness}

Farmers' perception of agribusiness was generally high with weighted mean average of 2.60. However, the lower perceptions of farmers are for the Pressures from global competition (2.04), Complex

\begin{tabular}{|c|c|c|c|c|c|c|c|}
\hline Items & SA & A & $\mathbf{U}$ & D & SD & $\begin{array}{l}\text { Weighted } \\
\text { sum }\end{array}$ & $\begin{array}{c}\text { Weighted } \\
\text { mean }\end{array}$ \\
\hline External factors like Climatic, Edaphic, Biotic, physiographic, socio-economic affect agribusiness & $\begin{array}{c}39 \\
(20.5)\end{array}$ & $\begin{array}{c}43 \\
(22.6)\end{array}$ & $\begin{array}{c}51 \\
(26.8)\end{array}$ & $\begin{array}{c}57 \\
(30.0)\end{array}$ & 0 & 504 & $2.65^{\star *}$ \\
\hline Agribusiness treats the different aspects of raising agricultural products as an integrated system & $\begin{array}{c}39 \\
(20.5)\end{array}$ & $\begin{array}{c}43 \\
(22.6)\end{array}$ & $\begin{array}{c}51 \\
(26.8)\end{array}$ & $\begin{array}{c}57 \\
(30.0)\end{array}$ & 0 & 506 & $2.66^{* *}$ \\
\hline The use of new technology is vital to remain competitive in the global agribusiness sector & $\begin{array}{c}16 \\
(8.4)\end{array}$ & $\begin{array}{c}71 \\
(37.4)\end{array}$ & $\begin{array}{c}48 \\
(25.3)\end{array}$ & $\begin{array}{c}55 \\
(28.9)\end{array}$ & 0 & 522 & $2.74^{* *}$ \\
\hline Countries with farming industries face consistent pressures from global competition & $\begin{array}{c}95 \\
(50.0)\end{array}$ & $\begin{array}{c}26 \\
(13.7)\end{array}$ & $\begin{array}{c}34 \\
(17.9)\end{array}$ & $\begin{array}{c}35 \\
(18.4)\end{array}$ & 0 & 389 & $2.04^{*}$ \\
\hline Farmers may also face a reduction in arable land as suburban and urban areas expand into their regions & $\begin{array}{c}39 \\
(20.5)\end{array}$ & $\begin{array}{c}43 \\
(22.6)\end{array}$ & $\begin{array}{c}51 \\
(26.8)\end{array}$ & $\begin{array}{c}57 \\
(30.0)\end{array}$ & 0 & 506 & $2.66^{* *}$ \\
\hline Agricultural business is profitable & $\begin{array}{c}40 \\
(21.1)\end{array}$ & $\begin{array}{c}42 \\
(22.1)\end{array}$ & $\begin{array}{c}46 \\
(24.2)\end{array}$ & $\begin{array}{c}53 \\
(27.9)\end{array}$ & 0 & 519 & $2.73^{* *}$ \\
\hline $\begin{array}{l}\text { Businesses unable to rapidly change in accordance with domestic demand may look to export their products } \\
\text { abroad, but if that fails they may not be able to compete and remain in business. }\end{array}$ & $\begin{array}{c}13 \\
(6.8)\end{array}$ & $\begin{array}{c}68 \\
(35.8)\end{array}$ & $\begin{array}{c}51 \\
(26.8)\end{array}$ & $\begin{array}{c}55 \\
(28.9)\end{array}$ & 0 & 588 & $3.09^{* *}$ \\
\hline $\begin{array}{c}\text { Agriculture depends on poorly paid labor that is often performed by migrant farmers, who are frequently } \\
\text { living in the country illegally. }\end{array}$ & $\begin{array}{c}34 \\
(17.9)\end{array}$ & $\begin{array}{c}71 \\
(37.4)\end{array}$ & $\begin{array}{c}37 \\
(19.5)\end{array}$ & $\begin{array}{c}48 \\
(25.3)\end{array}$ & 0 & 474 & $2.52^{*}$ \\
\hline The Kosovo government pays subsidies to farmers for grow commodity crops.. & $\begin{array}{c}39 \\
(20.5)\end{array}$ & $\begin{array}{c}51 \\
(26.8)\end{array}$ & $\begin{array}{c}43 \\
(22.6)\end{array}$ & $\begin{array}{c}57 \\
(30.0)\end{array}$ & 0 & 498 & $2.62^{* *}$ \\
\hline $\begin{array}{l}\text { Farmers today compete in a complex economic environment where customers choose from produce grown } \\
\qquad \text { all over the world }\end{array}$ & $\begin{array}{c}39 \\
(20.5)\end{array}$ & $\begin{array}{c}69 \\
(36.3)\end{array}$ & $\begin{array}{c}36 \\
(18.9)\end{array}$ & $\begin{array}{c}46 \\
(24.2)\end{array}$ & 0 & 469 & $2.46^{*}$ \\
\hline Management of processed agricultural products is not satisfactory & $\begin{array}{c}43 \\
(22.6)\end{array}$ & $\begin{array}{c}49 \\
(25,8)\end{array}$ & $\begin{array}{c}40 \\
(21.1)\end{array}$ & $\begin{array}{c}55 \\
(38.9)\end{array}$ & $\begin{array}{c}3 \\
(1.6)\end{array}$ & 491 & $2.61^{* *}$ \\
\hline Management of agricultural produce is satisfactory & $\begin{array}{c}47 \\
(24.7)\end{array}$ & $\begin{array}{c}61 \\
(32.1)\end{array}$ & $\begin{array}{c}40 \\
(21.1)\end{array}$ & $\begin{array}{c}42 \\
(22.1)\end{array}$ & 0 & 453 & $2.4^{*}$ \\
\hline Weighted mean sum & & & & & 0 & & 493.3 \\
\hline Weighted mean average & & & & & & & 2.60 \\
\hline
\end{tabular}

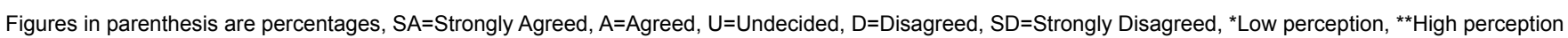
Table 2: Respondents' perception of agribusiness ( $n=190)$. 


\begin{tabular}{|c|c|c|c|}
\hline Management structure type & Co-efficient (Beta) & $\begin{array}{c}\text { Standard } \\
\text { error }\end{array}$ & T statistic \\
\hline Analyzers and descriptive & 1.8 & 0.37 & 4.89 \\
\hline Identifying and react & -0.005 & 0.27 & -0.01 \\
\hline Diagnostic and oversight & -0.8 & 0.17 & -4.46 \\
\hline Operational and controlling & -0.07 & 0.13 & -0.05 \\
\hline
\end{tabular}

Table 3: Types of structure management and changes in the economy.

\begin{tabular}{|c|c|c|c|}
\hline Management structure type & Co-efficient (Beta) & $\begin{array}{c}\text { Standard } \\
\text { error }\end{array}$ & T statistic \\
\hline Analyzers and descriptive & 1.42 & 0.14 & 9.97 \\
\hline Identifying and react & 0.007 & 0.1 & 0.06 \\
\hline Diagnostic and oversight & -0.43 & 0.07 & 6.29 \\
\hline Operational and controlling & 0.005 & 0.05 & 0.95 \\
\hline
\end{tabular}

Table 4: Types of structure management and harmonization of needs on rural areas.

economic environment (2.46), Satisfactory agricultural produce (2.40), Agriculture depends on poorly paid labor and often illegally (2.52).

A high farmers' perception is for external factors that affect agribusiness, treatment the different aspects of raising agricultural, the use of new technology, farmers may also face a reduction from the expand from of suburban and urban areas expand, agricultural is profitable, businesses unable to rapidly change in accordance with domestic demand, subsidies to farmer's form Kosovo government and agricultural products is not satisfactory. Means that farmers know about the negative impacts that affect their farms and how to facing with them is this result indicates a hope for agriculture in Kosovo.

\section{Hypotheses}

The regression analyses from Table 3 shows that the development of economy from all the modes of management improves to uses a more coordinated mode of structure management of farms. The result implies that the development of economy which may be attributed by their impact varies according to the modes structure management used. For instance, the farmers that use the mode of analysis and description as form to management their structure have highest average impact on the development of economy, followed by Identifying and react, Diagnostic and oversight, Operational and controlling.

Table 4 shows that there are no significant differences on harmonization of needs of people on rural areas from the change of the use of modes of structure management. The result implies that the harmonization of needs of people on rural areas. Further, it can be observed that the harmonization of needs of people on rural areas do not significantly differ from the change of use of modes of structure management. Therefore mean that, probably, it is not the type of modes structure management that really matters for people to harmonization their needs.

\section{Conclusion and Managerial Implications}

In this study, we compared impact in economy and harmonization of people needs across the type of modes structure management of farms. We revealed that farmers have high favorable perception of agribusiness, and the differences of impact of type of modes of structure managements differ. Different modes of structure management have impact in the economy of country, but the impact in people harmonization needs showed no significant differences.

The implication is that the farms in the republic of Kosovo should be able to build a coordinated types modes management of their structure as a great importance regarding economic development of the country as it can considerably contribute to the overall employment, as well as to the growth of Gross Domestic Product.

In addition, to improve the economy from the agriculture the country should also use appropriate policy options, for instance engendering commitment by government through appropriate legislative appropriation and budgetary commitment, ensures that appropriate logistic in form of credit is provided and ensuring that land is made available.

\section{Limitations and Directions for Future Research}

Whilst this study provides an important insight into the study of the impact of management of structure of agribusiness in economy of Kosovo, there are some limitations that have to be taken into consideration. One of them is that is limited only on the impact of management of structure in the economy, while agribusiness have impact on various aspect of country. The future research should therefore consider the impact of management of structure on agribusiness on social life of people, improving diversity of products, operation abroad etc. It is expected that this would enhance a broader understanding of the impact of structure of management of agribusiness and could be used as a basis for developing a more comprehensive and goal oriented performance scorecard which may serve as a guide for the selection of an appropriate types of modes of structure of management.

\section{References}

1. Westermarck $N$ (1951) The human factor and success in farming. Acta Agriculturae Scandinavia 3: 122-153.

2. Castle EN and Becker MH (1962) Farm business management: The decisionmaking process. Macmillan, New York, USA, p: 423

3. Muggen $G$ (1969) Human factors and farm management. A Review of the Literature World Agriculture and Rural Sociology 11: 1-11.

4. Tarabla HD and Dodd K (1990) Associations between farmer's personal characteristics, management practices and farm performance. British Veterinary Journal 145: 155-162.

5. Nuthall $P$ (2009) Modeling the origins of managerial ability in agricultura production. Australian Journal of Agricultural and Resource Economy 53: 413436

6. Rougoor CW, Trip G, Hurine R, Renkema A (1998) How to define and study farmers' management capacity: theory and use in agricultural economics. Agricultural Economics 18: 261-272.

7. Davis JH, Ray AG (1957) A Concept of Agribusiness, Harvard University, Boston, USA, pp: 1042-1045.

8. McConnell JD and Dillon JD (1997) Farm Management for Asia: A Systems Approach. University of New England 61: 98-105.

9. Gandhi VP (2014) Growth and transformation of the Agribusiness sector Drivers, Models and Challenges. Ind J Agri Econ 69: 11-13.

10. Goldsmith P (2016) International Food and Agribusiness Management Review Special Issue, University of Illinois, USA 19: 135-160.

11. Dobermann A and Nelson R (2013) Solutions for Sustainable Agriculture and Food Systems- Technical report for the post-2015 development agenda. Prepared by the Thematic Group on Sustainable Agriculture and Food Systems of the Sustainable Development Solutions Network pp: 5-17.

12. Acharya SS (2007) Agribusiness in India: Some Facts and Emerging Issues Agricultural Economics Research Review 20: 409-424.

13. Schickele R (1970) Farm management research for planning agricultural development, pp: 4-15

14. Stanton JV (2000) The role of agribusiness in development: Replacing the diminished role of the government in raising rural incomes. Journal of Agribusiness 18: 173-187. 
Citation: Sylejmani B (2018) The Impact of Management the Structure of Agribusiness on Development of Economy: Evidence from Republic of Kosovo. Int J Econ Manag Sci 7: 549. doi: 10.4172/2162-6359.1000549

Page 5 of 5

15. Beilock R (2005) Rethinking agriculture and Rural Development in Kosovo, University of Florida, 12: 23.

16. Bajrami E (2016) Evaluation of Agricultural Policy in the Dairy Sector in Kosovo and Efficiency Analysis at the Farm Level, University of Arkansas, Fayetteville 25: 109.

17. Mustafa MK and Gjokaj A (2016) Kosovo*: Agricultural Policy Development and Assessment. Joint research center pp: 2-10.

18. Gashi A (2017) Management of financial resources in the MAFRD of agriculture sector in Kosovo, pp: 12-30.

19. Miftari I, Waldhardt R, Bajrami E and Gjonbalaj M (2014) Supply scale and demand for agricultural advisory services in Kosovo, Ljubljana, Slovenia pp: 4-8.

20. Gjokaj E, Halimi K, Gjonbalaj M, Leeds S (2017) Agricultural Finance in Kosovo. Economic Alternatives 1: 79-80

21. Kutllovci E, Shala V (2011) The Impact of Strategic Planning on Small Business Growth in Kosovo pp: 2-6.

22. Statistic office of Kosovo (2001) Statistics on Agriculture in Kosovo.

23. Enhance youth Europe (2014) Study report from the main agribusiness subsectors in Kosovo pp: 66-79.

24. Zejnullahi ED (2014) Agriculture Sector in Kosovo and Opportunities for Cooperation with Balkans Countries, Turkish Journal of Agricultural and Natural Sciences 2: 1985-1990.

25. Kosovo Agency of Statistics (2011) Population Census, Households and Housing in Kosovo, pp: 23-45.

26. Task Force on European Integration (2014) Thematic Roundtable "Agriculture, Rural Development, Forestry, Fisheries, and Food Safety, pp: 4-6.

27. USAID (20150 Kosovo Agricultural Growth and Rural Opportunities, pp: 2-5.

28. The European Commission (2005) Kosovo Country Report, pp: 5-7.

29. Miftari I, Hoxha B, Gjokaj E (2015) Kosovo: Agricultural Policy Brief (CAPB). Pp: 1-16.

30. European Fund for Southeast Europe (2010) Agricultural finance in KosovoStudy Report pp: 3-15.
31. The World Bank (2016) Country Program Snapshot, pp: 5-19.

32. The European Commission (2013) Agricultural Land Pollution Survey (ALPS) in Kosovo pp: 22-50.

33. The Ministry of Agriculture, Forestry and Rural Development-MAFRD (2017) Agriculture and Rural Development Program pp: 20-48.

34. The European Commission and the World Bank (1999) A Program for Reconstruction and Recovery in Kosovo.

35. Arabiun AG (2014) The importance of Management for Growing and Developing Agribusiness SMEs: Designing a Conceptual Framework. International Review 25-50.

36. Makinen H (2013) Farmer's managerial thinking and management process effectiveness as factors of financial succession on Finnish dairy farms pp: 2-5.

37. The National Center for Appropriate Technology (2013) Tips about Farm Business Structures, pp: 1-2.

38. The International Institute for Environment and Development (2011) Participatory Research and On-Farm Management of Agricultural Biodiversity in Europe, pp: 100-102.

39. Wolz A, Fritzsch J and Reinsberg K (2005) The Impact of Social Capital on Farm and Household Income: Results of a Survey among Individual Farmers in Poland.

40. Gunderson MA, Boehlje MD, Neves MF, Sonka ST (2014) Agribusiness Organization and Management. Encyclopedia of Agriculture and Food Systems 1: $55-60$.

41. Mustafa I (2003) Kosovo Budget System-Policies and Sustainability. Riinvest p: 23.

42. Balzas K, Podmaniczky L, Szvetlana (2002) Drawing up Farm Management Plans for Agro-Environmental Schemes pp: 1-13.

43. Barnard CS and Nix JS (1973) Farm Planning and Control, ( $2^{\text {nd }}$ edn.), London. Cambridge University Press, p: 542.

44. Bitsch V (2009) Personnel Management Research in Agribusiness, p: 11-22. 